\title{
Effect of Fertigation and Mulching on Seed Yield and Quality Attributes in Okra Abelmoschus esculentus (L.) Moench
}

\author{
T. Senthivel ${ }^{2}$, N. S. Nagegowda ${ }^{1 *}$, S. Shankar Hebbar ${ }^{1}$ and M. Senthilkumar \\ ${ }^{1}$ Division of Vegetable Crops, ICAR-Indian Institute of Horticultural Research, \\ Bengaluru-89, Karnataka, India \\ ${ }^{2}$ Department of Agriculture and Animal Husbandry, Gandhigram Rural Institute, \\ Gandhigram-624 302, India \\ *Corresponding author
}

A B S T R A C T

\begin{tabular}{|l|}
\hline Ke y w o r d s \\
Fertigation, \\
mulching, Seed \\
yield and Seed \\
quality
\end{tabular}

\section{Introduction}

Water and nutrients are the two most critical inputs to be managed efficiently not only to increase the yield but also to sustain environmental safety and quality. Nutrient management is the most basic factor and is found to exert a great influence not only on growth and yield attributes of vegetables but also for obtaining sustained productivity. Among all nutrients; $\mathrm{N}, \mathrm{P}$ and $\mathrm{K}$ are three most important major nutrients which contribute to proper growth and yield of plants and it also has direct effect on

\begin{abstract}
An experiment was conducted during rabi 2016 and kharif 2017 to the study effect of precision farming technologies including fertigation and black polythene mulching to know the effect on growth yield and quality of okra seeds of var. ArkaAnamika. The experiment consisted often treatments was laid out in a Randomised Block Design (RBD) with three replications. The maximum seed yield (14.05 q/ha), 100 seed weight $(7.29 \mathrm{~g})$, index (384ion percentage $(94.33 \%)$, germination speed (24.68), vigour (19.77), vigour index (3841.31) and shoot and root length $(27.30 \& 13.42 \mathrm{~cm})$ of seedlings was recorded at mulched treatment. In general, the fertigation treatments in combination with mulching resulted in significantly higherseed quality attributes in okra.
\end{abstract}


this context, use of good quality vegetable seeds becomes necessary. An estimated 11,000 hectares presently produce vegetable seeds in the country. A continual attention is bestowed globally for systamatic fertilizer management for enhancing yield of vegetables but less attention is paid for producing seeds in vegetable crops. Good quality seed is one aspect that needs emphasis besides high yield of seed per se. In this context production of high quantities of good quality seeds in large number of vegetable crops over a significant area implies economic and ecological consideration at the national level. Among all the inputs seed play a vital role in ensuring higher yield and more income to the farmers. Quality seeds play a major role in vegetable yield as yield is a total outcome of various inputs such as quality seeds, optimum fertilizer usage, appropriate irrigation facilities and mechanisation. Precision farming technology is one of the methods in order to get better quality seeds.

Seed is the basic and most critical input in crop production. It carries the genetic potential of the improved variety. It acts as catalyst in posting the food grain production and also determinates are ultimate productivity of other inputs. The investments made on all other inputs will go waste if the seed is not of good quality, It is reported that mere use of quality seed alone can increase the yield by $15-20$ per cent and it can be raised by 35-40 per cent when combined with efficient crop management. The quality seed also offers to integrate the technologies for production, protection and quality enhancement in agriculture produce. Thus, use of quality seed is of paramount importance for sustainable agriculture production. The main role of other inputs and management practices in agriculture production is to harness the genetic potential of the vegetable seeds especially okra to the maximum extent.
Seed quality test mainly refers to germination and vigour tests. Standard laboratory germination tests describe the percentage of normal seedling under optimal conditions specified by the International Seed Testing Association (ISTA, 1999). This test, commonly used to evaluate seed quality, is able to predict field emergence provided the conditions for emergence are favorable. Many authors found laboratory germination tests to correlate well with field emergence (Szczepanska and Badania, 1982). Minimum limits of seed vigour can only be imposed in seed law enforcement, if we can get a test by which, we can establish the real value of a seed lot. High variation and low reproducibility among seed vigour test cause hindrance to the reliability of vigour test. Though laboratory germination is inadequate for predicting field value of a sample, the same is always practicable as a supplement of vigour test. Again most of the vigour tests need comparison under laboratory conditions and standard germination method which is best suited for the purpose. So farnot even a single study is available on fertigation and mulching in okra seed production.

\section{Materials and Methods}

The experiment was carried out at ICARIndian Institute of Horticultural Research, Hesaraghatta, Bengaluru during rabi 2016 and kharif 2017. The treatments comprised of four levels of fertigation with and without polyethylene mulching and two levels of fertilizer application through soil. The okra seeds of variety Arka Anamika were used for the experiment. The experiment comprised of ten treatments viz., $\mathrm{T}_{1}-100: 50: 75 \mathrm{NPK} \mathrm{kg} \mathrm{ha}{ }^{-1}$ through fertigation (WSF) with mulch, $\mathrm{T}_{2-}$ 100:50:100 NPK kg ha ${ }^{-1}$ through fertigation (WSF) with mulch, $\mathrm{T}_{3}-150: 75: 112.5 \mathrm{NPK} \mathrm{kg}$ $\mathrm{ha}^{-1}$ through fertigation (WSF) with mulch, $\mathrm{T}_{4}-150: 75: 150 \quad$ NPK $\mathrm{kg} \mathrm{ha}^{-1}$ through fertigation (WSF) with mulch, $T_{5}-100: 50: 75$ 
NPK $\mathrm{kg} \mathrm{ha}^{-1}$ through fertigation (WSF) without mulch, $\mathrm{T}_{6}-100: 50: 100 \mathrm{NPK} \mathrm{kg} \mathrm{ha}^{-1}$ through fertigation (WSF) without mulch, $\mathrm{T}_{7-}$ 150:75:112.5 NPK kg ha ${ }^{-1}$ through fertigation (WSF) without mulch, $\mathrm{T}_{8}$-150:75:150 NPK $\mathrm{kg} \mathrm{ha}^{-1}$ through fertigation (WSF) without mulch, $\mathrm{T}_{9}-100: 50: 100 \quad \mathrm{NPK} \quad \mathrm{kg} \mathrm{ha}^{-1}$ soil application of fertilizers without mulch and $\mathrm{T}_{10}-150: 75: 150$ NPK kg ha ${ }^{-1}$ soil application of fertilizers without mulch. Besides, a uniform basal application of farm yard manure @ 25 t/ha was done before sowing. The details of experiment is given below

\section{Crop/variety \\ 2. Variety \\ 3. Season}

4. Number of treatments : 10

5. Number of replication :3

6. Experimental Design

7. Spacing

8. Plot Size

\section{Quality analysis}

The processed seeds obtained from each treatment were tested for the following characteristics in the laboratory of the vegetable breeder seed unit, ICAR-IIHR, Bengaluru. The hundred seed weight in grams was recorded from each treatment as per the procedure suggested by (ISTA, 1999).

The laboratory test was conducted as per ISTA rules (ISTA, 1999) by adopting rolled towel method. Hundred seeds in three replications were taken at random from each treatment and uniformly placed on germination paper.

The rolled towel was kept in the germinator and maintained at a constant temperature of $25^{\circ} \mathrm{C}$ and 95 per cent relative humidity. The first and final count of germination was taken on $4^{\text {th }}$ and $21^{\text {st }}$ day respectively. The number of normal seedling was counted and the germination was expressed in per cent.

Ten normal seedlings in each treatment were randomly selected from germination test for measuring the root length on $21^{\text {st }}$ day of germination. The root length was measured from collar region to the tip of the root. Average root length of ten seedlings was computed and expressed in $\mathrm{cm}$. The same seedlings were used for measuring the shoot length also. It was measured from the collar region to the point of attachment of cotyledon. The average was computed and expressed in $\mathrm{cm}$.

The seedlings used for measuring the seedling length were packed in a butter paper bag and dried for $24 \mathrm{hrs}$ in a hot air oven maintained at $80^{\circ} \mathrm{C}$. The dreid ones were removed and cooled in desssicators for 30 minutes. Then the weight was recorded and expressed in $\mathrm{mg}$ per seedling. The vigour index values were calculated as per the method prescribed by Abdul-Baki and Andreson (1973) and expressed in a whole number

Vigour index (VI) = Germination (\%) $\mathrm{x}$ [Shoot length $(\mathrm{cm})+$ Root length $(\mathrm{cm})$ ]

High speed of germination is an indication of vigorous seed lot. Number of germinated seed counted every day from the first day and the cumulative index is made by the formula (Maguire, 1962)

Speed of germination $=\sum(\mathrm{n} / \mathrm{t})$

Where $\mathrm{n}$ is the number of seeds newly germinating at time $t$ and $t$ is days from sowing

\section{Results and Discussion}

From the pooled data of two seasons, it was observed that all the fertigation treatments 
either with or without the combination of mulch recorded significantly higher yield than fertilizer applied through soil. Among the treatments $\mathrm{T}_{4}$ (fertigation of WSF with mulch) recorded higher seed yield (14.05 q/ha) and was on par with $\mathrm{T}_{3}(14.02 \mathrm{q} / \mathrm{ha})$ followed by $\mathrm{T}_{1}(11.96 \mathrm{q} / \mathrm{ha})$ and $\mathrm{T}_{2}(11.76 \mathrm{q} / \mathrm{ha})$. Among the treatment of fertigation of WSF without mulch $\mathrm{T}_{8}$ and $\mathrm{T}_{7}$ recorded higher seed yield of $11.83 \mathrm{q} /$ ha an $11.73 \mathrm{q} / \mathrm{ha}$ respectively.

The fertilizer applied through soil resulted in significantly lower yield in both $\mathrm{T}_{9}$ (8.70 $\mathrm{q} / \mathrm{ha}$ ) and $\mathrm{T}_{10}(9.92 \mathrm{q} / \mathrm{ha})$. The ultimate goal in any crop production is to maximize the yield and quality. In okra also, the seed quality is very important from the consumer point of view and the seed quality is largely judged by the test weight, germination vigour and vigour index of the seeds. Hundred seed weight is an important attribute which decides the boldness of the seed. Higher hundred seed weight means bolder seeds and hence more will be the seed yield and seed vigour which are the most important characters in seed quality.

In the present investigation, maximum 100 seed weight was recorded with WSF through fertigation and mulch in $\mathrm{T}_{4}(7.29 \mathrm{~g})$ as compared to fertilizer applied through soil without mulch $\left(\mathrm{T}_{10}-6.61 \mathrm{~g}\right)$. This may be due to the good quality and bigger fruits resulted in bold seeds. Test weight of okra seed was increased with increased level of potassium as reported by Bhende et al., (2015). Similar trends were reported by Mani et al., (1980) and Kotur, (2013). Germination percentage is one of the key criteria for determining the physiological aspect of the seed and gives an idea about the ability of seed to produce normal and healthy seedling under the normal field condition. In the present study, the fertigation treatments in combination with mulching resulted in significantly higher germination in both the seasons. The combined application of fertigation and mulch $\left(\mathrm{T}_{4}\right)$ resulted in higher germination (94.33 per cent) as compared to 88.33 per cent obtained in $\mathrm{T}_{8}$ (WSF applied through fertigation without mulch). Application of fertilizers through soil $\left(\mathrm{T}_{10}\right)$ resulted in 80.17 per cent.

Among the fertigation with mulch treatments, the higher seed per plant recorded in $\mathrm{T}_{4}$ was on par with $T_{3}$ followed by $T_{2}$ and $T_{1}$ with WSF through fertigation and mulch. This may be due to the bigger sized seeds possess well developed embryo which could be the reason for greater seed viability as against smaller seeds and also the increase in germination in larger seed might be due to increased activity of redox-enzyme helping in breaking down the complex food material in to simple soluble sugars in the okra seeds as reported by Yakkala Siva Sankar and Arghya Mani (2015). These results are similar to the findings of Wood et al., (1997), Dronawall (1985) and Bhende et al., (2015). Polythene mulch maintains optimum temperature and soil moisture during the maturation of the seed and these factors might have resulted in bold and vigorous seeds.

Germination speed is one of the important factors, which decides the quality of the seeds and also quantifies the seedling vigour. The fertigation treatments in combination with mulch resulted in significantly higher germination speed in both the field experiments. The combined application of fertigation and mulch resulted in 22.68 higher germination speed than the WSF through fertigation without mulch treatments and fertilizers through soil application (12.79). Among the treatments of fertigation with mulch, WSF applied through fertigation with mulch $\left(\mathrm{T}_{4}\right)$ resulted in higher germination speed and was on par with $\mathrm{T}_{3}$ followed by $\mathrm{T}_{1}$ and $\mathrm{T}_{2}$ i.e., application of fertilizer through fertigation with mulch (Table 1). 
Table.1 Effect fertigation and polyethylene mulching on okra seed yield and its quality attributes

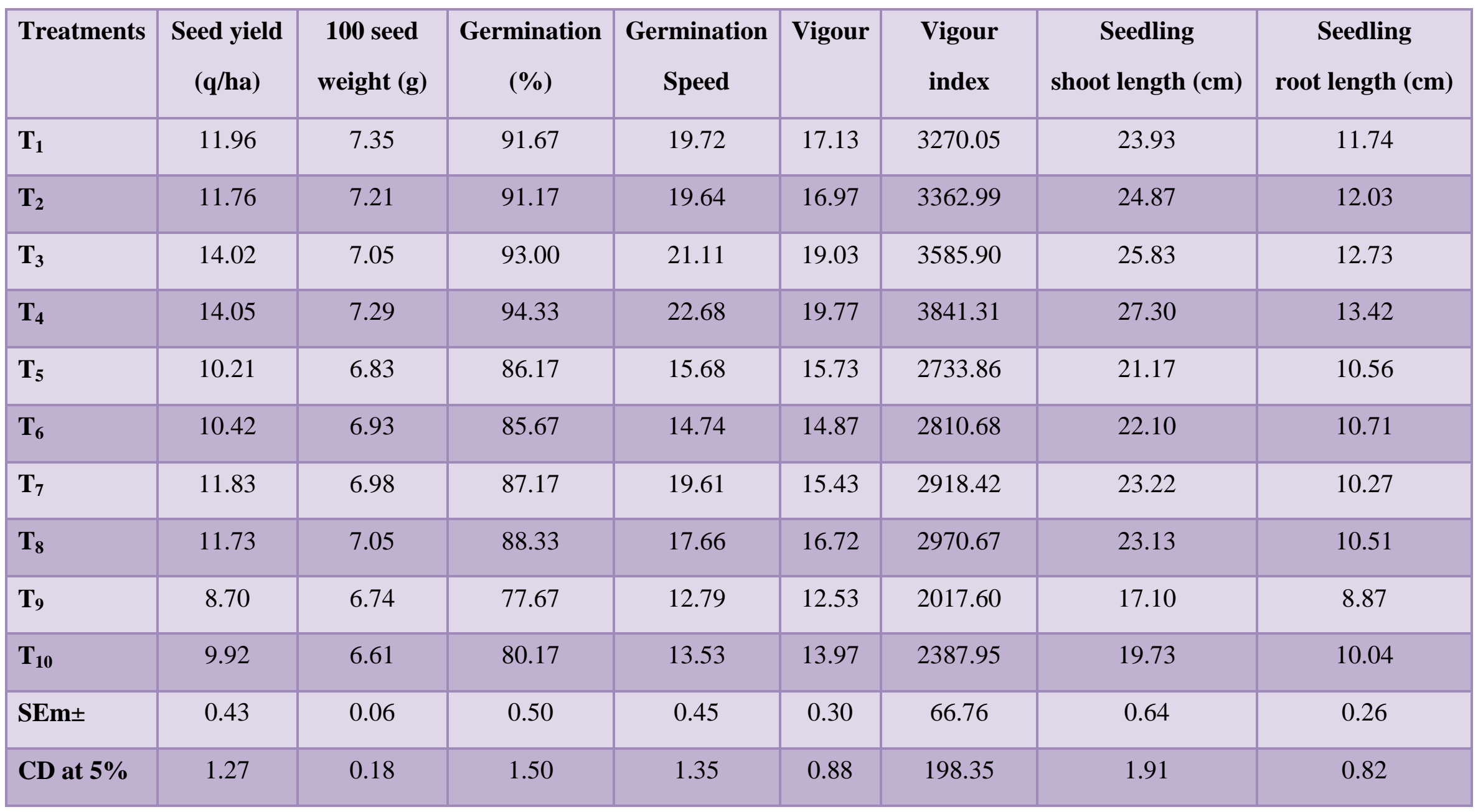


The fertigation and mulch treatments resulted in maximum speed of germination and also maximum seed vigour. Faster initiation of activity within the seeds as a result of imbibed chemical might have triggered the speed of germination as reported by Yakkala Siva Sankar and Arghya Mani (2015). These results are in line with the findings of Maguire (1962).

Vigour is defined by the ISTA as the sum total of those properties of the seed which determine the potential level of activity and performance of a dormant seed. The vigour and vigour index was recorded with a numerically maximum value by application of fertilizer through fertigation and mulch whereas the application of fertilizer through soil resulted with the minimum vigour and vigour index value. The vigour was recorded with the numerically maximum value in the $\mathrm{T}_{4}(19.97 \mathrm{mg})$ and on par with $\mathrm{T}_{3}$ (19.03mg) and the minimum dry seedling weight value in $\mathrm{T}_{9}$ with a mean value of $12.53 \mathrm{mg}$. These results corroborate the findings of Brain et al., (1955), Singh et al., (1979) and Pollack and Roos (1972). The faster germination and a better translocation of food reserves to growing seedlings might have resulted in higher dry weight of seedlings. The dry seedling weight indicated the superiority of larger size seeds over other grades. The relatively higher vigour associated with larger size could also be ascribed to well matured embryo containing adequate nutrient reserves both contributing its physiological stamina or vigour factor residing in it. The maximum vigour index was recorded at the treatment $\mathrm{T}_{4}$ (3841.31) which was on par with $\mathrm{T}_{3}(3585.90)$ and the minimum vigour index of 2017.60 was observed at soil application treatment $\left(\mathrm{T}_{9}\right)$, however among fertigation treatments without mulch the treatment $\mathrm{T}_{8}$ recorded higher vigour index value (2970.67) and on par with treatment $\mathrm{T}_{7}$ (2918.42). These results are in line with the findings of Perry (1972) that the seed vigour is not equivalent of seed germinability. Similar observations have also been made by other workers Singh, (2018), Headu et al., (2010), Yakkala Siva Sankar and Arghya Mani (2015) Chattopadhyay et al., (2011).
Shoot length and root length of seedlings are important quality parameters. The fertigation treatments in combination with mulching resulted in significantly higher seedling shoot and root length in both the cropping seasons. The two seasons pooled data revealed that the combined application of fertigation and mulch $\left(\mathrm{T}_{4}\right)$ resulted with higher seedling shoot and root length $27.30 \mathrm{~cm}$ and $13.42 \mathrm{~cm}$ respectively as compared to application WSF through fertigation without mulch in $\mathrm{T}_{8}(23.63 \mathrm{~cm}$ and $10.53 \mathrm{~cm}$ ) and fertilizers applied through soil in $\mathrm{T}_{9} \quad(17.10 \mathrm{~cm}$ and $8.87 \mathrm{~cm})$. Among the fertigation treatments with mulch, the higher seedling shoot and root length recorded in $\mathrm{T}_{4}$ was on par with $T_{3}$ followed by $T_{2}$ and $T_{1}$ with WSF through fertigation and mulch. This may be due to greater amount of food reserves contained and the greater embryo size in the seed as reported by Yakkala Siva Sankar and Arghya Mani (2015). These results are similar to the findings of Pollack and Roos (1972).The seedling length showed the superiority of larger size seeds over other grades. The relatively higher vigour associated with larger size could also be ascribed to the well matured embryo containing adequate nutrient reserves both contributing its physiological stamina or vigour factor. Wood et al., (1977) also reported that the seedling shoot and root length increased with increase in the seed weight. Similar trends were also obtained in okra seedling by Headu et al., (2010).

\section{References}

Abdul-Baki, A.A. and Andreson, J.D. 1973. Vigour determination in soyabean by multiple criteria. Crop Sci., 13:630633.

Abusaleha, and Shanmugavelu, K.G.1988. Studies on the effect of organic vs. inorganic source of nitrogen on growth, yield and quality of okra (Abelmoschus esculentus). Indian J. Hort., 45(3-4): 312-318.

Bhende, S.K., H. K. Deshmukh, P. K., Nimbolkar, R. K., Dewangan, and A.H. Nagone. 2015. Effect of phosphorous 
and potassium on quality attributes of okra cv. ' Arka Anamika'. Int. J. Environ. Sci., 6(2): 226-231.

Brain, P.W. and H.G. Hemming. 1955. The Effect of GA on Shoot Growth of Pea Seedling, Physiol Plant., 8: 669-681.

Chattopadhyay, A., S. Dutta, and S. Chatterjee. 2011. Seed yield and quality of okra as influenced by sowing Dates. African J Biotech., 10(28): 5461-5467.

Dronawall, S. 1985. A Study of Genetic Regulation on Seed Viability and Vigour in Rice (Oryza sativa L.), M.Sc. (Ag) thesis, Tamil Nadu Agiculture University, Coimbatore.

Headu, N.K., V. Gyanendra Singh, S.R.K. Mahajan, Singh and Anita Gahlain. 2010. Seed quality and vigour in relation to nodal position and harvesting stage of okra under mid hills of north western Himalayas. Indian J. Hort. 67 (Special issue):251-253.

ISTA, 1999. International rules for testing seeds. Seeds Sci. and Techn. 27:155175.

Kotur, S.C., 2013. Fertilizer management of vegetable and seed purpose okra with emphasis on yield, $\mathrm{N}$ and $\mathrm{P}$ fertilizer use efficiency and seed quality. Ind. J. of fert., 9(3):70-74

Magurie, J.D., 1962. Speed of Germination Aid in Selection an Evaluation for Seedling Emergence and Vigour, Crop Sci., 2:176-177.

Mani, S. and K. M., Ramanathan, 1980.Effect of nitrogen and potassium on the yield of bhendi. South Indian Hort., 28: 136138.

Meenakshi, N., (2002). Growth and productivity of hybrid bittergourd [Momordica charantia (L.)] $\mathrm{CoBgoH}-1$ under different macro and micronutrient fertigation levels, Ph.D. (Hort.) Thesis, Tamil Nadu Agricultural University, Coimbatore, T.N. (INDIA).

Pollack, B.M. and E.E. Roos, 1972. Seed Biology I.T.T. Kozlowaski, Academic Press New York, pp. 313-387.

Singh, D.P., Chaubey. T., and B. Singh, 2018. Response of okra seed production to bio-fertilizers. Veg. Sci., 45 (1): $42-44$

Singh, H.K., G. Shankar, and M. Makhiza.1979, A Study on Citrus Seed Germination as Affected by Some Chemicals, Haryana J. Hortl. Sci., 8:194-195.

Szczepanska-kolasinska, and K. Badania. 1982. Wartoscisiewnejnasionroznych from soi (Glycine $\max \quad$ L.) warunkach laboratoryjnych I polowych. Hod Roslin Aklim, 26(3):189-226.

Wood, D.W., P.C. Longden, and R.K. Scott. 1977. Seed Size Variation-Its Extents Source and Significance in Field Crops, Seed Sci. Technol., 5: 387-352.

Yakkala Siva Sankar and Arghya Mani. 2015. Studies on Seed Quality Parameters of Okra (Abelmoschus esculentu sL.). J. Agric. Technol., 2(1\&2): 79-83.

\section{How to cite this article:}

Senthivel, T., N.S. Nagegowda, S. Shankar Hebbar and Senthilkumar, M. 2019. Effect of Fertigation and Mulching on Seed Yield and Quality Attributes in Okra Abelmoschus esculentus (L.) Moench. Int.J.Curr.Microbiol.App.Sci. 8(04): 1707-1713. doi: https://doi.org/10.20546/ijcmas.2019.804.200 